\title{
Electrocatalysis at Nanometer and Sub-Nanometer Scales: Hydrogen Evolution on Supported MoS2 and Mo3S4 Clusters
}

Jaramillo, Thomas; Jørgensen, Kristina Pilt; Saadi, Souheil; Bonde, Jacob Lindner; Zhang, Jingdong; Ooi, Bee Lean; Nielsen, Jane Hvolbæk; Horch, Sebastian; Ulstrup, Jens; Nørskov, Jens Kehlet Total number of authors:

11

Published in:

Meeting Abstracts - Electrochemical Society

Publication date:

2006

Document Version

Publisher's PDF, also known as Version of record

Link back to DTU Orbit

Citation $(A P A)$ :

Jaramillo, T., Jørgensen, K. P., Saadi, S., Bonde, J. L., Zhang, J., Ooi, B. L., Nielsen, J. H., Horch, S., Ulstrup, J., Nørskov, J. K., \& Chorkendorff, I. (2006). Electrocatalysis at Nanometer and Sub-Nanometer Scales: Hydrogen Evolution on Supported MoS2 and Mo3S4 Clusters. In Meeting Abstracts - Electrochemical Society (pp. Abstract 99). The Electrochemical Society.

\section{General rights}

Copyright and moral rights for the publications made accessible in the public portal are retained by the authors and/or other copyright owners and it is a condition of accessing publications that users recognise and abide by the legal requirements associated with these rights.

- Users may download and print one copy of any publication from the public portal for the purpose of private study or research.

- You may not further distribute the material or use it for any profit-making activity or commercial gain

- You may freely distribute the URL identifying the publication in the public portal 
Electrocatalysis at nanometer and sub-nanometer scales: Hydrogen evolution on supported $\mathrm{MoS}_{2}$ and $\mathrm{Mo}_{3} \mathrm{~S}_{4}$ clusters

Thomas F. Jaramillo ${ }^{1}$, Kristina P. Jørgensen ${ }^{1}$, Souheil Saadi ${ }^{2}$, Jacob Bonde ${ }^{1}$, Jingdong Zhang ${ }^{3}$, Bee Lean $\mathrm{Ooi}^{3}$, Jane H. Nielsen ${ }^{1}$, Sebastian Horch ${ }^{2}$, Jens Ulstrup ${ }^{3}$, J.K. Nørskov ${ }^{2}$, Ib Chorkendorff ${ }^{1}$

${ }^{1}$ Center for Individual Nanoparticle Functionality, CINF, Nano ·DTU, Department of Physics

${ }^{2}$ Center for Atomic-scale Materials Physics, CAMP, Nano·DTU, Department of Physics

${ }^{3}$ Nano·DTU, Department of Chemistry

Buildings $312^{1}, 307^{2}$, and $206^{3}$, Technical University of Denmark DK-2800 Lyngby, Denmark

Clean, alternative energy carriers will be needed as fossil fuel reserves are depleted. One possible energy carrier under consideration is $\mathrm{H}_{2}$, which can be produced cleanly and renewably if solar or wind energy is coupled to water electrolysis. Unfortunately, the hydrogen evolution reaction (HER) is catalyzed most effectively by Pt group metals ${ }^{1}$ - materials that are expensive and scarce. New materials are needed if this scheme is to ever become viable.

Having studied different metal surfaces and enzymes that catalyze hydrogen evolution, we have found a necessary criterion, a "descriptor", for high catalytic activity - the binding energy (Gibbs free energy) of atomic hydrogen adsorption must be close to zero. ${ }^{1,2}$ Not surprisingly, the nitrogenase and hydrogenase enzymes both of which evolve $\mathrm{H}_{2}$ in nature - satisfy this requirement. In an effort to develop solid-state analogues of the enzymatic active sites, theoretical calculations have guided us to $\mathrm{MoS}_{2}$ nanoparticles and $\mathrm{Mo}_{3} \mathrm{~S}_{4}$ complexes, which were subsequently synthesized and investigated for hydrogen evolution.

Having already confirmed the catalytic activity of $\mathrm{MoS}_{2}$ nanoparticles for hydrogen evolution ${ }^{2}$, more recently we have aimed to identify relationships between structure and catalytic activity within the $\mathrm{MoS}_{2}$ nanoparticles. In our approach, we combine ultra high vacuum techniques with electrochemical measurements under ambient conditions. $\mathrm{MoS}_{2}$ nanoparticles were first synthesized on $\mathrm{Au}(111)$ in ultra-high vacuum, where scanning tunnelling microscopy (STM) was used to investigate their structure, morphology, and surface coverage (Fig. 1). Surface spectroscopy was also employed for chemical characterization. These UHVprepared samples were then transferred to an electrochemical cell where catalytic activity for hydrogen evolution was measured. By varying particle size and coverage within the sample set, our measurements have established - for the first time - a clear relationship between the structure and catalytic activity of $\mathrm{MoS}_{2}$ nanoparticles.

Bearing in mind the active edge state in $\mathrm{MoS}_{2}$ nanoparticles ${ }^{2}$, we have looked to other solid-state systems which also mimic the active site within nitrogenase and/or hydrogenase. One candidate material is an aquo, tri-nuclear molybdenum complex, $\left[\mathrm{Mo}_{3} \mathrm{~S}_{4}\right]^{4+}$, which we have synthesized following the procedure in reference 3 (see Fig. 2). Our theoretical model predicts these complexes to be active for hydrogen evolution, and to investigate them experimentally we have deposited them as individual, separate entities onto an inert HOPG substrate. We subsequently characterized these catalysts using STM, surface spectroscopy, and electrochemical methods. The supported $\mathrm{Mo}_{3} \mathrm{~S}_{4}$ complexes demonstrated excellent catalytic activity for hydrogen evolution, just below that of the Pt-group metals, per active site.
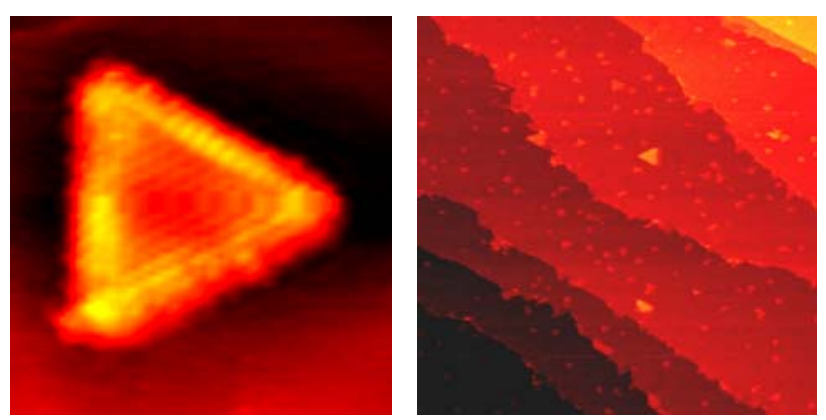

Fig. 1. STM images (width $7 \mathrm{~nm}$ and $150 \mathrm{~nm}$ ) of $\mathrm{MoS}_{2}$ nanoparticles on $\mathrm{Au}(111)$.

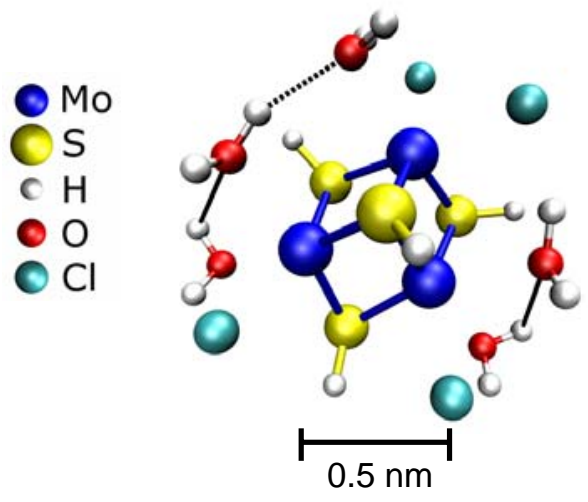

Fig. 2. DFT-calculated structure of the protonated $\left[\mathrm{Mo}_{3} \mathrm{~S}_{4}\right]^{4+}$ complex in aq. $\mathrm{HCl}$.

\section{References}

${ }^{1}$ J.K. Nørskov, T. Bligaard, A. Logadottir, J.R. Kitchin, J.G. Chen, S. Pandelov, U. Stimming, J. Electrochem. Soc. 152, J23 (2005).

${ }^{2}$ B. Hinnemann, P.G. Moses, J.Bonde, K.P. Jørgensen, J.H. Nielsen, S. Horch, I. Chorkendorff, J.K. Nørskov, J. Am. Chem. Soc., 127, 5308 (2005).

${ }^{3}$ H. Akashi, T. Shibahara, and H. Kuroya, Polyhedron, 9 , 1671 (1990). 